\title{
Working
}

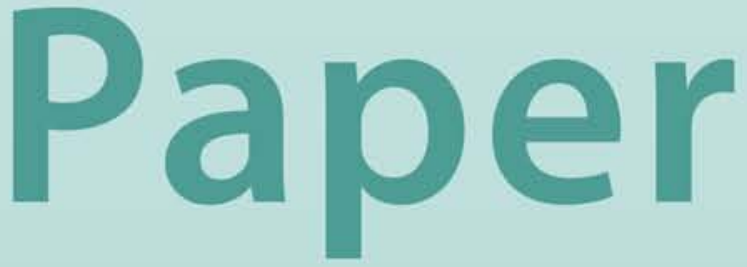




\section{Trade Elasticities and Market Expectations in Brazil}

Claudio Paiva 


\title{
IMF Working Paper
}

IMF Institute

\section{Trade Elasticities and Market Expectations in Brazil}

\author{
Prepared by Claudio Paiva ${ }^{1}$
}

\author{
Authorized for distribution by Eric V. Clifton
}

July 2003

\begin{tabular}{l} 
Abstract \\
\begin{tabular}{|l} 
The views expressed in this Working Paper are those of the author(s) and do not necessarily \\
represent those of the IMF or IMF policy. Working Papers describe research in progress by the \\
author(s) and are published to elicit comments and to further debate.
\end{tabular} \\
\hline
\end{tabular}

This paper provides econometric estimates of trade elasticities for Brazil obtained through cointegration and vector auto regression models and controlling for the effects of exchange rate volatility, capacity utilization, and changes in import tariffs. The results suggest that (i) recent market expectations may have been unduly pessimistic regarding the responsiveness of Brazil's trade flows to the real exchange rate, but (ii) the GDP growth rates targeted by the new government may put downward pressure on the exchange rate and thus render the achievement of official inflation targets considerably more difficult if structural reforms are not implemented.

JEL Classification Numbers:F14; F41; C22

Keywords: Trade; elasticities; exchange rate; cointegration models

Author's E-Mail Address: cpaiva@imf.org

\footnotetext{
${ }^{1}$ I am grateful to Ricardo Gazel, Roberto Guimaraes, Eric Clifton, Andrew Feltenstein, Joshua Greene, Yuko Kinoshita, Trevor Alleyne, Lorenzo Perez, Phil Gerson, and Agnes Belaisch for valuable comments. Taryie Isoun provided excellent research assistance. The usual disclaimer applies.
} 


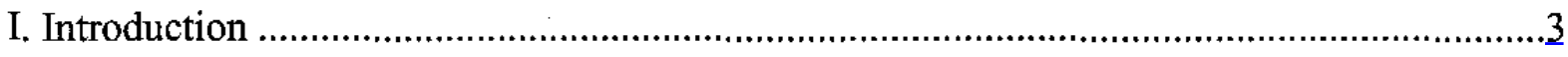

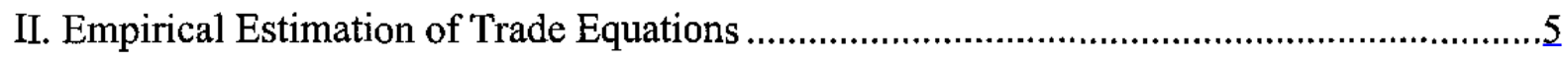

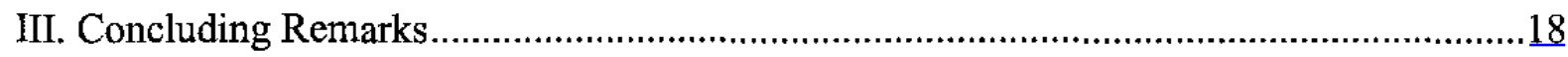

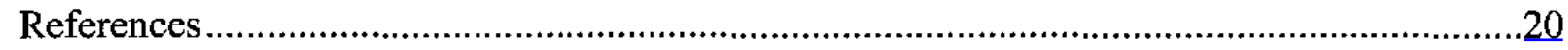

Tables

1: Variables' Description and Unit-Root Tests.............................................................

2: Long-Run Export Elasticities - Summary of Cointegration Models .................................. 9

3: Import Elasticities - Summary of Cointegration Models ................................................14

4: Selected Import VARs and the Impact of Tariffs on Import Volumes............................17

\section{Figures}

1: Daily Exchange Rate BRL x USD, 2001 ..................................................................4

2: Market Expectations Polled in Jan.-Nov. 2001 .........................................................

3: Selected Export Models - Fitted vs. Actual Values ...................................................11

4: Selected Import Models - Fitted vs. Actual Values ...................................................15 


\section{INTRODUCTION}

Can Brazil rely on its floating exchange rate with inflation targeting regime to maintain its external accounts on a sustainable path and reduce inflation while allowing a pickup in economic activity? How effective is this policy framework in minimizing the domestic impact of adverse external shocks? The answers to these questions are fundamentally tied to the income and price elasticities of Brazil's international trade flows. The higher the income elasticity of exports relative to that of imports and the higher the price elasticities of trade, the smaller is the exchange rate depreciation necessary to preserve current account sustainability amid accelerating GDP growth. ${ }^{2}$ The responsiveness of trade flows to changes in the exchange rate is also key to reduce the domestic impact of an adverse external environment. Avoiding a significant depreciation of the Brazilian real (BRL), in turn, is desirable to facilitate the achievement of the inflation targets.

The improvement in the trade balance observed over the two years that followed the January 1999 floating and ensuing depreciation of the BRL was well below what had been expected by the government and most market analysts. Brazil's trade deficit was reduced only by US $\$ 6$ billion (about 6 percent of total trade flows) between 1998 and 2000 , even though the real effective exchange rate (REER) depreciated by nearly 30 percent and the pace of domestic economic growth was similar to that of Brazil's main trading partners. This relatively modest adjustment raised market concerns about the existence of structural rigidities that would require a substantial depreciation of the BRL in order to preserve the sustainability of the external accounts as domestic growth accelerates and/or the international environment deteriorates, generating some type of "trade elasticity pessimism" among financial market agents.

The possibility that market expectations are somewhat contaminated by trade elasticity pessimism is of particular importance since expectations of (an excessive) depreciation may negatively affect capital flows and become self-fulfilling, giving rise to a currency overshooting with potentially serious destabilizing effects. Jeanne and Rose (2002) and Devereux and Engel (2002) show that foreign currency traders with biased expectations of future exchange rates can generate high exchange rate volatility. Moreover, evidence of the emergence of exchange rate bubbles in Brazil in recent years has been presented by Maldonado, Tourinho, and Valli (2002).

Economic data and information on financial market expectations suggest that trade elasticity pessimism was widespread among financial market analysts while the BRL depreciated by almost 30 percent against the U.S. dollar (USD) in the 10 months through October 2001 (Figure 1). During that period, weekly surveys conducted by the Brazilian Central Bank with about 50 of the main financial analysts in Brazil and abroad show a curious pattern in which: (i) the aforementioned exchange rate depreciation was expected to be maintained at least through the end of 2002; (ii) inflation projections increased only

\footnotetext{
${ }^{2}$ The relationship between relative income trade elasticities and growth rates in multicountry groups has been addressed by studies that include Krugman (1989) and Caporale and Chui (1999).
} 
marginally and remained below 7 percent a year, indicating that the nominal depreciation of the BRL was expected to translate into a substantial REER depreciation; (iii) the domestic GDP growth rate was expected to drop below that of Brazil's main trading partners in 2001-02; and (iv) nonetheless, the trade balance was expected to remain virtually unchanged in 2001 and improve only marginally by about 3 percent of trade volumes in 2002 (Figure 2). As further indication that trade elasticity pessimism was an important factor behind the currency volatility in 2001 , the nominal exchange rate reversed its trend and appreciated sharply in the last two months of that year, when concrete signs of a strong turn around in the trade balance became unequivocal. ${ }^{3}$

Figure 1: Daily Exchange Rate BRL x USD, 2001

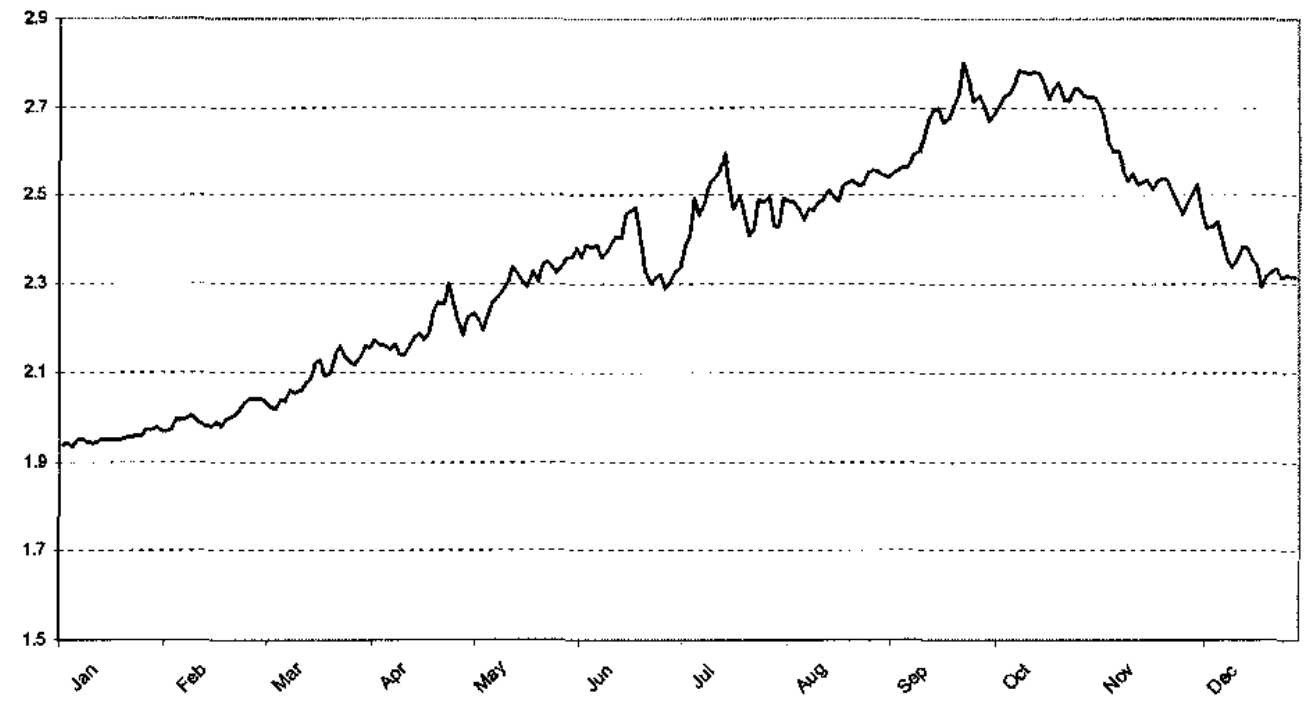

Source: Brazilian Central Bank

This paper provides a comprehensive set of estimates of trade elasticities for Brazil obtained from cointegration and unrestricted vector auto regression models using quarterly data from 1991:1 to 2001:4 and control variables such as the level of capacity utilization in manufacturing, REER volatility, and average import tariffs. The estimated elasticities are in line with the international experience, dismissing the view that Brazil is an outlier in terms of structural trade rigidities. Our results also suggest that the weaker than expected improvement in the trade balance between 1998 and 2000 may have been related to the REER volatility and fast-rising capacity utilization in the manufacturing sector that were observed during that period. In addition, the estimated magnitudes of income elasticities of trade imply that achieving the targeted GDP growth rates of at least 4 percent under current conditions could place some pressure on the REER to depreciate in order to maintain a trade surplus consistent with a sustainable external position. This potential pressure on the

\footnotetext{
${ }^{3}$ See Figueiredo et al. (2002) for details on the turnaround in the foreign exchange market in
} late 2001 and the importance of the trade adjustment in this process. 
exchange rate therefore underscores the importance of the government's structural reform agenda to improve competitiveness and economic growth while facilitating the disinflation process.

Figure 2: Market Expectations Polled in Jan.-Nov. 2001

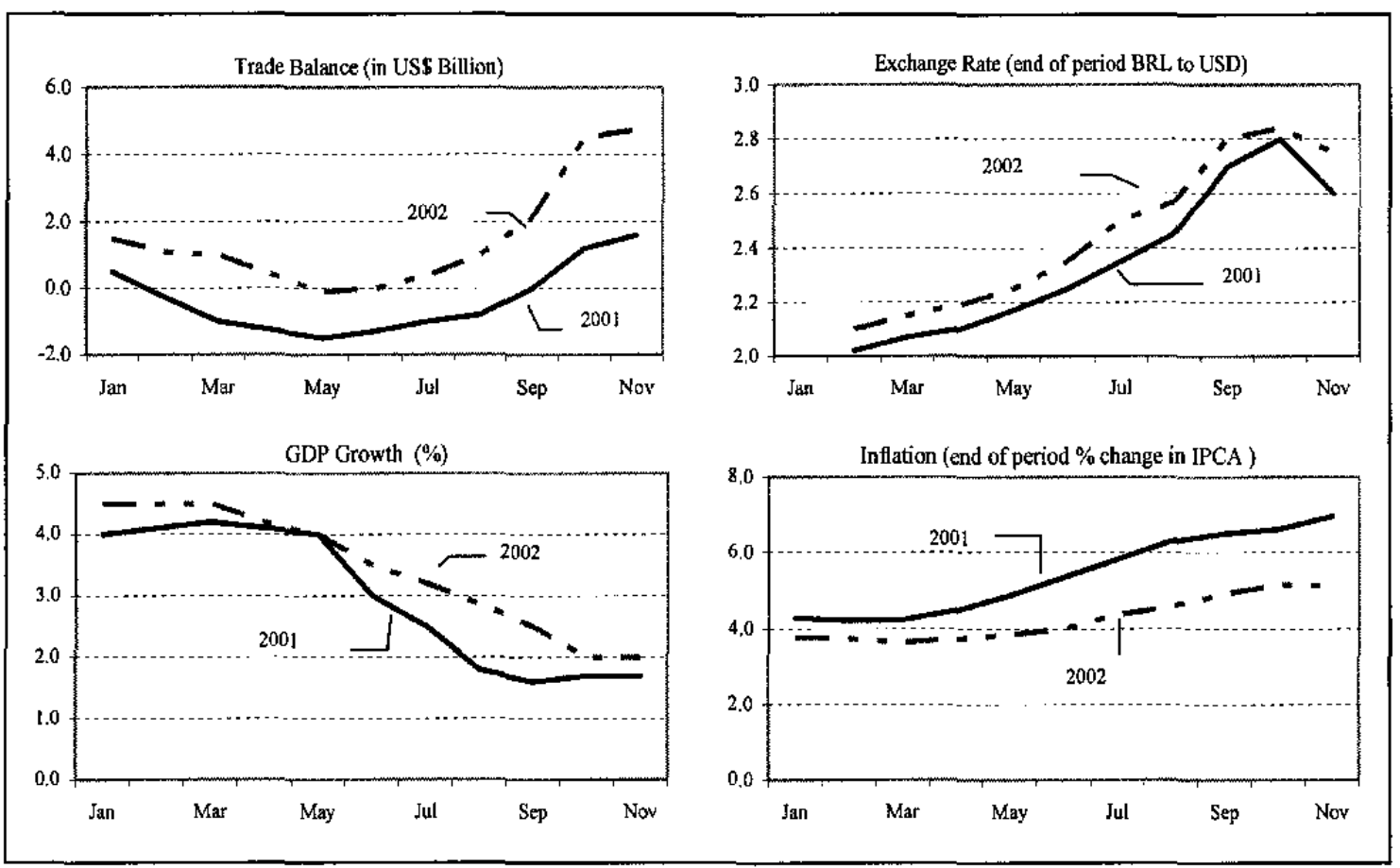

Source: Brazilian Central Bank

\section{EMPIRICAL ESTIMATION OF TRADE EQUations}

The number of recent empirical studies of trade elasticities in Brazil is limited. Cavalcanti and Ribeiro (1998) model the behavior of Brazil's main export categories using monthly data for the period 1977-98. Somewhat surprisingly, they fail to establish the significance of external demand for the determination of export volumes, which are solely explained by a measure of relative profitability and a time trend. Their study indicates that various breaks in the relationship among the models' endogenous variables may have occurred during the 1980 s, probably reflecting the government's extensive use of nonmarket export incentives and the various attempts at inflation stabilization which resorted to price controls and fixing the exchange rate. ${ }^{4}$

Carvalho and Parente (1999) study the behavior of the main import categories in a cointegration framework using monthly data for the period 1978-96. They find import income elasticities ranging from 1.3 for capital goods to 1.7 for durable consumption goods and relative price elasticities ranging from -1.4 for nondurable to -2.9 for durable

${ }^{4}$ See Baer (2001) for details. 
consumption goods. ${ }^{5}$ In addition, they estimate that a 1 percent increase in the level of capacity utilization increases the imports of capital and non-durable goods by about 6.4 percent and 7.1 percent, respectively, in the long run.

Resende (2001) finds surprisingly low and nonsignificant elasticities of imports with respect to GDP and relative prices during the period 1978-98. However, the estimated income elasticity increases to 3.8 when the sample period is restricted to begin in 1990 . Similarly, the absolute value of the price elasticity increases to 1.4 when the sample period is restricted to begin after inflation stabilization in the second half of $1994 .^{6}$ Estimates of income elasticities for individual import categories ranged from 1.5 for nondurable consumption goods to 3.5 for capital and intermediate goods.

Building on this past research experience, in this paper we use quarterly data covering the period 1991:1-2001:4 to estimate trade equations for Brazil. We present models for total export and import volumes as well as for the main categories of exports and imports. Basic export models that relate trade volumes to foreign demand and relative price variables are estimated, analyzed, and subsequently expanded to include other potentially important variables such as a measure of exchange rate volatility and the level of capacity utilization in domestic manufacturing. ${ }^{7}$ Similarly, basic import equations are later expanded to include the level of capacity utilization and changes in import tariffs. Some models are also augmented to incorporate seasonal dummy variables.

The series for Brazilian GDP, total export and import volumes, export and import volumes by main categories, and capacity utilization in domestic manufacturing were taken from the Brazilian Institute of Applied Economic Research (IPEA). The real effective exchange rate series was taken from the IMF's World Economic Outlook (WEO). The series for partner countries' GDP was built using data obtained from the WEO and the same weights used by the IMF to calculate the REER for Brazil. ${ }^{8}$ All series were transformed by applying natural logarithm.

As in many studies, including Arize, Osang, and Slottje (2000) and Aristotelous (2001), exchange rate volatility (VOL) is measured by the moving average of the standard deviation of the logarithm-transformed real effective exchange rate series (REER):

\footnotetext{
${ }^{5}$ The measure of relative prices used in this study combine international prices, the bilateral exchange rate between the BRL and the U.S. dollar, and a domestic wholesale price index.

${ }^{6}$ The measure of relative prices used combine international prices, the bilateral exchange rate BRL-USD, and (unspecified) measures of BRL prices of domestic substitute goods.

${ }^{7}$ Most theoretical models addressing the impact of exchange rate volatility on exports show that the profit uncertainty introduced by volatility reduces the interest of risk-averse firms in exporting their products. See McKenzie (1999) for a survey of these models.

${ }^{8}$ These weights take into account the importance of each country for Brazil as a direct trade partner and also as a competitor in third markets.
} 


$$
V O L_{t}=\left[(1 / m) \cdot \sum_{i=1}^{m}\left(R_{1+i-1}-R_{t E R_{t+i-2}}\right)^{2}\right]^{1 / 2}
$$

where the order of the moving average is determined by setting $m=4$.

All series used in the model estimations are listed and described in Table 1, which also summarizes the results of Augmented Dickey-Fuller (ADF) tests for the existence of unit roots. $^{9}$

Table 1: Variables' Description and Unit-Root Tests

\begin{tabular}{|c|c|c|c|c|}
\hline YARABLE & RANGE & MEAN & ADF & ADF T \\
\hline $\mathbf{X}$ is the natural log of total export volumes & 4.24-5.07 & 4.67 & $-1.29(4)$ & $-2.96(4)$ \\
\hline XBAS is the natural log of export volumes of basic goods & $4.16-5.40$ & 4.71 & $0.51(4)$ & $-0.76(4)$ \\
\hline $\mathbf{X M}$ is the natural log of export volumes of manufactured goods & $4.25-5.01$ & 4.68 & $-2.06(0)$ & $-3.19(0)$ \\
\hline XSM is the natural log of export volumes of semi-manufactures & $3.87-4.91$ & 4.55 & $-1.92(4)$ & $-3.95^{*}(2)$ \\
\hline $\mathbf{M}$ is the natural log of total import volumes & $4.15-4.80$ & 4.25 & $-2.18(0)$ & $-2.00(0)$ \\
\hline MIG is the natural log of import volumes of intermediate goods & $3.17-4.94$ & 4.29 & $-2.09(0)$ & $-2.22(0)$ \\
\hline MK is the natural log of import volumes of capital goods & $3.09-5.04$ & 4.20 & $-1.95(4)$ & $-1.46(4)$ \\
\hline MD is the natural log of import volumes of consumer durables & $2.16-5.49$ & 4.13 & $-2.76(4)$ & $-1.77(0)$ \\
\hline MND is the natural log of import volumes of non-durables & $2.77-4.83$ & 3.99 & $-2.22(4)$ & $-1.51(4)$ \\
\hline MOIL is the natural log of oil import volumes & $3.73-4.75$ & 3.37 & $-5.5^{* *}(0)$ & $-5.3^{* *}(0)$ \\
\hline GDP is the natural log of real GDP in Brazil & $4.50-4.90$ & 4.76 & $-1.06(2)$ & $-1.38(5)$ \\
\hline GDPX is the natural log of Brazilian real GDP excluding exports & $4.40-4.75$ & 4.63 & $-1.19(2)$ & $-0.07(5)$ \\
\hline PARGDP is the natural log of real GDP in Brazil's trade partners & $4.60-4.88$ & 4.74 & $-0.37(5)$ & $-1.60(5)$ \\
\hline VOL is the moving average of the standard deviation of REER & $0.2-16.2$ & 3.34 & $-1.93(1)$ & $-2.39(1)$ \\
\hline $\begin{array}{l}\text { CUM is the natural log of the capacity utilization in } \\
\text { manufacturing }\end{array}$ & $4.23-4.45$ & 4.38 & $-2.74(5)$ & $-2.14(5)$ \\
\hline \multicolumn{5}{|c|}{ where ${ }^{*}$ denotes rejection of the null hypothesis of a unit root at 5-percent significance level and } \\
\hline
\end{tabular}

The fourth column of the table indicates the ADF statistic obtained from the standard test regression including an intercept and a number of lagged difference terms which is indicated in parenthesis; the last column shows the ADF statistic obtained from the standard regression including an intercept, a trend, and a number of lagged difference terms which is indicated in parenthesis. The number of lags of the differenced variable included in the test regression was determined so as to minimize the Schwarz criterion, starting from a maximum of five lags. The tests indicate that all variables, except for the volume of oil imports, can be

${ }^{9}$ See Enders (1995) for a description of the ADF test. 
treated as nonstationary. Stationarity is achieved through first differencing (the unit-root tests for the series in first differences are omitted for simplicity but are available upon request). These results suggest that the estimation of trade models be made considering and appropriately testing for the existence of cointegrating relationships among the variables.

\section{a) Export Models}

Trace statistics obtained from the Johansen $(1998,1991)$ procedure suggest that all export models have one cointegrating equation. In this case, the dynamics of export volumes can be represented by an error-correction equation such as:

$$
\Delta X_{t}=\alpha\left(X_{t-1}-\delta_{n} \Psi_{t-1}+C_{1}\right)+\sum_{i=1}^{l} \rho_{i} \Delta X_{t-i}+\sum_{i=1}^{l} \omega_{n, i} \Delta \Psi_{t-i}+C_{2}+Q D_{t}+\varepsilon_{t}
$$

where $\alpha$ is the coefficient on the error-correction term; $\delta_{n}$ is a $(1 \times n)$ vector of coefficients in the cointegrating relation; $\Psi$ represents a $(\mathrm{n} \times 1)$ vector with the $n$ endogenous variables other than exports; $\omega_{\mathfrak{n}}$ is the $(1 \mathrm{x} \mathrm{n})$ vector of short-term coefficients on the first differences of the endogenous variables in the ( $\mathrm{n} \times 1)$ vector $\Delta \Psi ; \mathrm{C}_{1}$ and $\mathrm{C}_{2}$ are constants; $\mathrm{QD}$ is a quarterly seasonal dummy variable; and $\varepsilon$ is a disturbance term. ${ }^{10}$ The coefficients in $\delta_{n}$ can be interpreted as the long-term elasticities of exports to the other $n$ endogenous variables in the system, and $\alpha$ indicates the speed at which export volumes adjust to their long-term determinants. The models for exports by main categories have an analogous form, with $\mathrm{X}$ being replaced by XBAS, XM, or XSM in equation (2).

In the estimation and model selection process, the maximum lag length $l$ in each model was determined so as to minimize the Schwarz criterion. Subsequently, lag exclusion Wald tests were used to identify any lag $i<l$ that did not reach the 10 percent significance level, which was then omitted from the specification. Table 2 summarizes the best models estimated for total exports and for the main export categories. The numbers in parentheses are standard deviations of the coefficient estimates. Trace statistics generated by Johansen cointegration tests applied to final model specifications confirm the existence of one cointegrating equation at the 1 percent significance level for all models reported.

Models (1) and (2) indicate that Brazilian exports have long-run income (PGDP) and real exchange rate (REER) elasticities which are in line with the international experience. ${ }^{11}$ In addition, the coefficients $\alpha$ on the error-correction term suggest that export volumes rapidly converge to their long-term equilibrium path. The models display an excellent insample fit, as indicated by the adjusted R-squared ratio, the Schwarz criterion (SC), and the graphs displayed in Figure 3.

${ }^{10}$ As suggested in Johansen (1995), centered seasonal dummy variables are used so as not to affect the trend of the level series.

${ }^{11}$ See, for example, Senhadji and Montenegro (1999), Caporale and Chui (1999), and Arize (1995). 
Table 2: Long-Run Export Elasticities - Summary of Cointegration Models

\begin{tabular}{|c|c|c|c|c|c|c|c|c|}
\hline Model & PGDP & REER & QD & VOL & CUDM & $\alpha$ & $\begin{array}{l}\text { Adj } \\
\text { RSQ }\end{array}$ & $\mathbf{S C C}$ \\
\hline \multicolumn{9}{|c|}{ Total Exports } \\
\hline (1) & $\begin{array}{c}1.5 \\
(0.14)\end{array}$ & $\begin{array}{c}-0.29 \\
(0.07)\end{array}$ & No & & & $\begin{array}{l}-1.07 \\
(0.21)\end{array}$ & 0.81 & -2.18 \\
\hline (2) & $\begin{array}{c}1.5 \\
(0.17)\end{array}$ & $\begin{array}{c}-0.34 \\
(0.08)\end{array}$ & Yes & & & $\begin{array}{c}-0.89 \\
(0.19)\end{array}$ & 0.85 & -2.34 \\
\hline (3) & $\begin{array}{c}1.5 \\
(0.35)\end{array}$ & $\begin{array}{c}-0.56 \\
(0.18)\end{array}$ & No & $\begin{array}{c}-0.19 \\
(5.5)\end{array}$ & & $\begin{array}{l}-0.38 \\
(0.14)\end{array}$ & 0.81 & -1.72 \\
\hline (4) & $\begin{array}{c}2.1 \\
(0.14)\end{array}$ & $\begin{array}{c}-0.37 \\
(0.05)\end{array}$ & Yes & & $\begin{array}{c}-0.80 \\
(0.17)\end{array}$ & $\begin{array}{c}-0.49 \\
(0.16)\end{array}$ & 0.91 & -2.49 \\
\hline \multicolumn{9}{|c|}{ Exports of Basic Goods } \\
\hline (5) & $\begin{array}{c}1.5 \\
(0.10)\end{array}$ & $\begin{array}{c}-0.55 \\
(0.11)\end{array}$ & No & & & $\begin{array}{c}-0.49 \\
(0.13)\end{array}$ & 0.96 & -1.54 \\
\hline (6) & $\begin{array}{c}1.8 \\
(0.22)\end{array}$ & $\begin{array}{c}-0.64 \\
(0.11)\end{array}$ & Yes & $\begin{array}{c}-0.16 \\
(3.7)\end{array}$ & & $\begin{array}{c}-0.27 \\
(0.16)\end{array}$ & 0.94 & -1.38 \\
\hline \multicolumn{9}{|c|}{ Exports of Manufactured Goods } \\
\hline (7) & $\begin{array}{c}1.3 \\
(0.07)\end{array}$ & $\begin{array}{c}-0.32 \\
(0.08)\end{array}$ & No & & & $\begin{array}{c}-0.56 \\
(0.14)\end{array}$ & 0.61 & -2.38 \\
\hline (8) & $\begin{array}{c}1.8 \\
(0.34)\end{array}$ & $\begin{array}{c}-0.26 \\
(0.15)\end{array}$ & Yes & & & $\begin{array}{c}-0.37 \\
(0.06)\end{array}$ & 0.78 & -2.80 \\
\hline (9) & $\begin{array}{c}1.4 \\
(0.18)\end{array}$ & $\begin{array}{c}-0.44 \\
(0.19)\end{array}$ & Yes & $\begin{array}{c}-0.26 \\
(6.3)\end{array}$ & & $\begin{array}{c}-0.29 \\
(0.04)\end{array}$ & 0.83 & -2.62 \\
\hline (10) & $\begin{array}{c}2.4 \\
(0.24)\end{array}$ & $\begin{array}{c}-0.34 \\
(0.11)\end{array}$ & No & & $\begin{array}{c}-1.3 \\
(0.29)\end{array}$ & $\begin{array}{c}-0.28 \\
(0.14)\end{array}$ & 0.70 & -1.96 \\
\hline \multicolumn{9}{|c|}{ Exports of Semimanufactured Goods } \\
\hline (11) & $\begin{array}{c}1.9 \\
(0.18)\end{array}$ & $\begin{array}{c}-0.16 \\
(0.08)\end{array}$ & No & & & $\begin{array}{c}-0.54 \\
(0.32)\end{array}$ & 0.50 & -1.01 \\
\hline (12) & $\begin{array}{c}1.3 \\
(0.08)\end{array}$ & $\begin{array}{c}-0.35 \\
(0.08)\end{array}$ & Yes & $\begin{array}{r}-0.14 \\
(2.3)\end{array}$ & & $\begin{array}{c}-0.82 \\
(0.21)\end{array}$ & 0.73 & -1.37 \\
\hline
\end{tabular}

The basic export model is expanded to consider the impact of real effective exchange rate volatility (VOL) on exports. Model (3) shows that VOL has a negative and significant impact on export volumes. Similar results were obtained for other countries as shown in Arize, Osang, and Slottje (2000), Darrat and Hakim (2000), and McKenzie (1999). The estimated coefficient and sample range for VOL suggest that during the period of highest exchange rate uncertainty export volumes may have been depressed by almost 3 percent.

Once the negative effects of exchange rate volatility are controlled for, exports appear to be significantly more responsive to the trend in the real exchange rate, as indicated by the higher absolute value on the long-run coefficient of the REER. This augmented model also shows a slower adjustment toward long-term equilibrium. These results may help explain why exports did not improve as some had expected immediately following the floating and devaluation of the exchange rate in January 1999, since the Brazilian currency displayed significant volatility around that period. Ignoring the negative impact of exchange rate 
volatility on exports may lead to an overshooting of the exchange rate (and more volatility) if agents mistake this effect for a lack of responsiveness of exports to the trend in the real effective exchange rate. ${ }^{12}$

Model (4) expands the basic export model to include the level of capacity utilization in domestic manufacturing (CUDM). The estimated coefficient on this variable has a negative sign and is significant, indicating that capacity utilization constraints had a negative impact on Brazil's exports in the sample period. It suggests that a 1 percent increase in the level of capacity utilization in manufacturing may lower export volumes by 0.8 percent. Controlling for this supply constraint yields a higher estimated elasticity of exports to foreign income and to the real exchange rate, as intuitively expected. This model displays the best fit among the export models.

The dynamics of the main exports categories are featured in models (5) through (12). Income and price elasticities estimated for the individual export categories are generally consistent with the elasticities estimated for aggregate volumes. Somewhat surprisingly, income elasticity estimates obtained from the basic models (5), (7), and (11) do not vary significantly across different export categories. However, once the level of capacity utilization in manufacturing is included in model (10), the estimated income elasticity of exports of manufactured goods become significantly higher than that of basic exports.

The exports of basic goods seem to be more responsive to the real exchange rate than other export categories. Brazil's natural resources, notably the abundance of arable land and year-around moderate climate, renders agricultural production very responsive to price incentives. A depreciation of the real exchange rate may significantly increase both the area cultivated and the productivity of the land through more intensive use of technology. In addition, the low differentiation of commodities suggests that Brazil may not face severe demand constraints in these sectors, so that production and exports may be more responsive to price incentives.

${ }^{12}$ The possibility that the type of exchange rate regime had a significant impact on exports (beyond its implication for the REER) was tested with the inclusion of different dummy variables in various VAR specifications. These variables failed to reach minimum significance levels or to significantly improve the fit of the models. 
Figure 3: Selected Export Models - Fitted vs. Actual Values

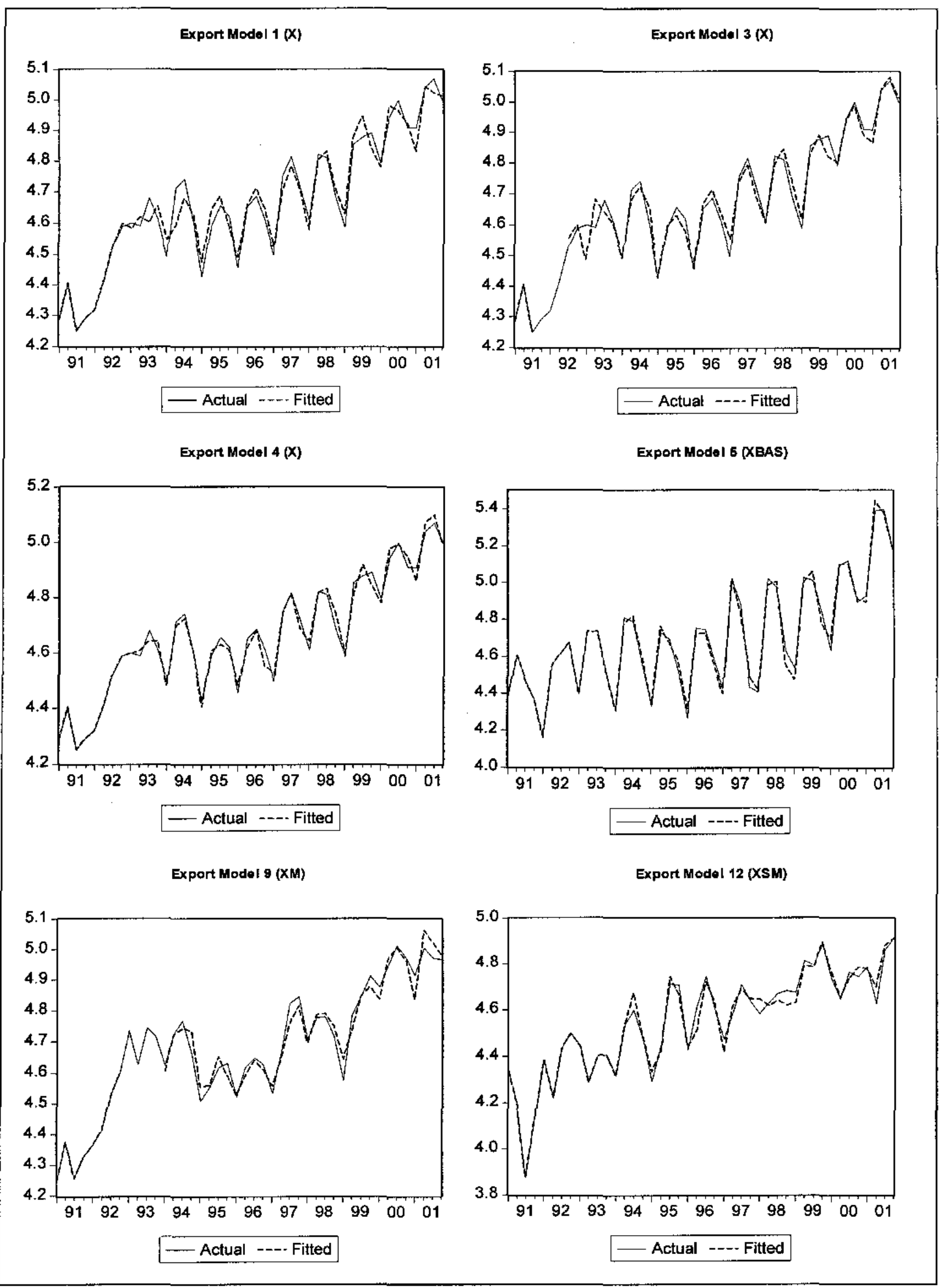


Models (6), (9), and (12) show that the coefficients on the real exchange rate volatility estimated in for individual export categories are negative, significant, and have magnitudes which are consistent with the estimated impact of this variable on aggregate exports. The estimates indicate that exports of manufactured goods are the most affected by exchange rate volatility. Also in accordance with the results obtained from the aggregate export models, accounting for the negative effect of the real exchange rate volatility on the main categories of exports increases their estimated responsiveness to the REER but slows the convergence of export volumes toward their long-term levels.

\section{b) Import Models}

Trace statistics obtained from the Johansen $(1998,1991)$ procedure suggested that all basic models relating import volumes, domestic GDP, and the REER have one cointegrating equation. The dynamics of import volumes can thus be represented by an error-correction equation such as:

$$
\begin{aligned}
& \Delta M_{t}=\alpha\left(M_{t-1}-\delta G D P_{t-1}-\lambda R E E R_{t-1}+C_{1}\right)+\sum_{i=1}^{l} \rho_{i} \Delta M_{t-i}+ \\
& +\sum_{i=1}^{l} \omega_{i} \Delta G D P_{t-i}+\sum_{i=1}^{l} \phi_{i} \Delta R E E R_{t-i}+C_{2}+\varepsilon_{t}
\end{aligned}
$$

where $\alpha$ is the coefficient on the error-correction term; $\rho_{i}, \omega_{i}$, and $\varphi_{i}$ are the coefficients on the $i$-th lag of the differenced import volumes, GDP, and REER, respectively; $\mathrm{C}_{1}$ and $\mathrm{C}_{2}$ are constants; and $\varepsilon$ is a disturbance term.

Seasonal dummies are not included since they did not improve the fit of import VECMs, probably reflecting the fact that imports and GDP follow a similar seasonal pattern. The coefficients in the error correction term in parentheses can be interpreted as the longterm elasticities of imports to GDP and the REER, and $\alpha$ indicates the speed at which export volumes adjust to their long-term determinants. The models for imports by categories have an analogous form, with $\mathrm{M}$ being replaced by MIG, MK, MD, MND in equation (3).

The Johansen trace statistics indicate that models (14), (16), and (20), which include the level of capacity utilization in domestic manufacturing, have two cointegrating vectors. Moreover, likelihood ratio (LR) test statistics indicate that CUDM should not be considered weakly exogenous in the import models estimated. Import volumes in the VECM with two cointegrating relations would have the following dynamics:

$$
\begin{aligned}
& \Delta M_{t}=\alpha\left(M_{t-1}-\delta \mathrm{GDP}_{t-1}-\lambda R E E R_{t-1}+C_{1}\right)+\beta\left(C U D M_{t-1}-\kappa G D P_{t-1}-\right. \\
& \left.-\eta R E E R_{t-1}+C_{2}\right)+\sum_{i=1}^{l} \rho_{i} \Delta M_{t-i}+\sum_{i=1}^{l} \gamma_{i} \Delta C U D M_{t-i}+\sum_{i=1}^{l} \omega_{i} \Delta G D P_{t-i}+ \\
& +\sum_{i=1}^{l} \phi_{i} \operatorname{REER}_{t-i}+C_{3}+v_{t}
\end{aligned}
$$


where $\beta$ is the coefficient on the second error-correction term, capturing the response of import volumes to deviations of the level of capacity utilization in manufacturing from its long-term value; $\gamma_{\mathrm{i}}$ is the coefficient on the $i$-th lag of the differenced level of capacity utilization in domestic manufacturing; $\mathrm{C}_{1}, \mathrm{C}_{2}$, and $\mathrm{C}_{3}$ are constants; $v$ is a disturbance term; and the remaining symbols are as defined in equation (3).

Table 3 summarizes the best models estimated for total imports and for the main import categories. Numbers in parentheses denote the standard errors of the coefficient estimates. The process of model selection was the same applied to export models. All models have good in-sample fit, as indicated by the adjusted R-squared ratio and the Schwarz criterion (SC). The goodness of fit of some selected models is also apparent from the graphs depicted in Figure 4.

Model (13) indicates that Brazilian imports have long-run income and REER elasticities of about 3.2 and 0.6 , respectively. These values are broadly in line with the international experience and estimates carried out for Brazil in earlier studies. ${ }^{13}$ The coefficients $\alpha$ on the error-correction term suggest that import volumes converge quickly to their long-term equilibrium: 95 percent of deviations from long-term values are eliminated after only one quarter.

Trace statistics suggest the existence of two cointegrating vectors at 1 percent significance when import models are expanded to include the level of capacity utilization in domestic manufacturing. The coefficient $\beta$ estimated in model (14) indicates that for each percentage point that the current capacity utilization CUDM exceeds its long-term value as implied by the other endogenous variables, import volumes grow by 3 percentage points. Once this supply constraint is controlled for, the estimated long-run elasticities of imports to domestic GDP and the REER are reduced to 2.6 and 0.3 , respectively. Although the speed of adjustment of import volumes toward long-term values decreases in the augmented model (as $\alpha$ declines to 0.47 ), it remains relatively high, with 92 percent of a deviation from long-term value being eliminated after 4 quarters.

Models (15) through (20) address the dynamics of individual import categories. In the basic models that relate import volumes to GDP and REER only, long-run income elasticities vary from 2.1 in the case of nondurable consumer goods to 4.0 in the case of durable consumption goods, while the elasticities with respect to the REER range from 0.24 for intermediate goods to 2.45 for consumer durables. These estimates are compatible with the mostly nonessential nature of durable goods, whose demand thus appears more elastic with respect to income and (relative) prices when compared to other import categories. The lower elasticity of imported intermediate goods to the REER is also intuitively expected, since a large portion of these goods consists of inputs to export activities which have a symmetric response to exchange rate movements and thus work to partially offset the direct impact of the REER on this category of imports.

${ }^{13}$ See, for example, Senhadji (1998) and Resende (2001). 
Table 3: Import Elasticities - Summary of Cointegration Models

\begin{tabular}{|c|c|c|c|c|c|c|}
\hline Model & RGDP & REER & $\boldsymbol{\beta}$ & $\mathbf{\alpha}$ & $\begin{array}{l}\text { Adj. } \\
\text { RSQ }\end{array}$ & SCPII \\
\hline \multicolumn{7}{|c|}{ Total Imports } \\
\hline (13) & $\begin{array}{c}3.2 \\
(0.19)\end{array}$ & $\begin{array}{c}0.57 \\
(0.07)\end{array}$ & & $\begin{array}{c}-0.94 \\
(0.16)\end{array}$ & 0.89 & -1.88 \\
\hline (14) & $\begin{array}{c}2.6 \\
(0.54)\end{array}$ & $\begin{array}{c}0.30 \\
(0.14)\end{array}$ & $\begin{array}{c}3.0 \\
(1.95)\end{array}$ & $\begin{array}{c}-0.47 \\
(0.15)\end{array}$ & 0.89 & -1.71 \\
\hline \multicolumn{7}{|c|}{ Imports of Intermediate Goods } \\
\hline (15) & $\begin{array}{c}3.6 \\
(0.29)\end{array}$ & $\begin{array}{c}0.24 \\
(0.14)\end{array}$ & & $\begin{array}{c}-0.85 \\
(0.14)\end{array}$ & 0.81 & -1.39 \\
\hline (16) & $\begin{array}{c}4.6 \\
(0.26)\end{array}$ & $\begin{array}{c}0.23 \\
(0.14)\end{array}$ & $\begin{array}{c}2.6 \\
(1.1)\end{array}$ & $\begin{array}{c}-1.03 \\
(0.25)\end{array}$ & 0.68 & -0.89 \\
\hline \multicolumn{7}{|c|}{ Imports of Durable Goods } \\
\hline (17) & $\begin{array}{c}4.0 \\
(0.63)\end{array}$ & $\begin{array}{c}2.45 \\
(0.31)\end{array}$ & & $\begin{array}{c}-0.94 \\
(0.16)\end{array}$ & 0.64 & 0.90 \\
\hline \multicolumn{7}{|c|}{ Imports of Nondurable goods } \\
\hline (18) & $\begin{array}{c}2.1 \\
(0.54)\end{array}$ & $\begin{array}{c}0.80 \\
(0.15)\end{array}$ & & $\begin{array}{c}-0.68 \\
(0.10)\end{array}$ & 0.76 & -0.69 \\
\hline \multicolumn{7}{|c|}{ Imports of Capital Goods } \\
\hline (19) & $\begin{array}{c}3.3 \\
(0.69)\end{array}$ & $\begin{array}{c}0.41 \\
(0.23)\end{array}$ & & $\begin{array}{c}-0.53 \\
(0.14)\end{array}$ & 0.76 & -0.41 \\
\hline (20) & $\begin{array}{c}2.9 \\
(0.87)\end{array}$ & $\begin{array}{c}0.40 \\
(0.25)\end{array}$ & $\begin{array}{c}4.9 \\
(2.1)\end{array}$ & $\begin{array}{c}-0.43 \\
(0.10)\end{array}$ & 0.74 & -0.67 \\
\hline
\end{tabular}


Figure 4: Selected Import Models - Fitted vs. Actual Values

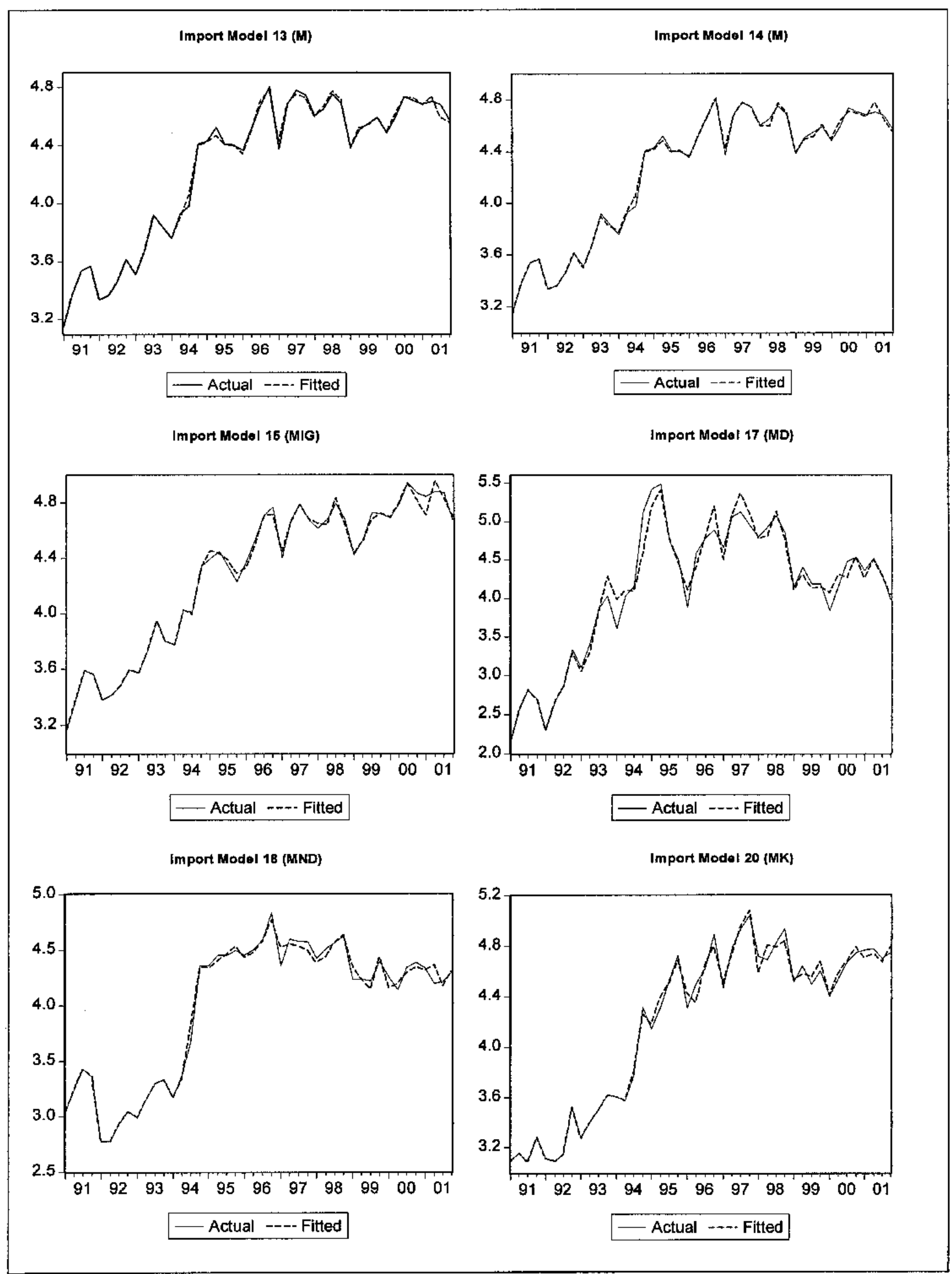


The expanded models (14) and (20) show that the impact of CUDM on individual import categories is positive, significant, and consistent with its impact on aggregate imports. As expected, imports of capital goods appear more responsive than aggregate imports to increased capacity constraints in manufacturing. Including CUDM in the modeling of consumer goods did not yield satisfactory estimates.

Unrestricted vector autoregressive Models (VARs) were estimated in order to analyze the behavior of oil imports and the impact of changes in import tariffs on various import categories. ${ }^{14}$ The import equation in the VAR has the following general specification:

$$
\Delta M_{t}=\sum_{i=1}^{l} \rho_{i} \Delta M_{t-i}+\sum_{i=1}^{l} \omega_{i} \Delta G D P_{t-i}+\sum_{i=1}^{l} \varphi_{i} \Delta R E E R_{t-i}+C_{1}+D T_{t}+\varepsilon_{t}
$$

where $\mathrm{C}_{1}$ is a constant and $\mathrm{DT}_{t}$ is a dummy variable whose value equals the percentage change in average import tariffs implemented discretely over the sample period. ${ }^{15}$ The number of lags $l$ in the vector of endogenous variables was determined so as to minimize the Schwarz criterion with $0<l<5$.

Table 4 summarizes the best VARs estimated. Models (21) through (23) indicate that the changes in average import tariffs had a negative and significant impact on aggregate import volumes. The estimated coefficient on the tariff dummy and lagged dependent variable indicate that import volumes in the long run increase about 0.5 percent for each one percent reduction in average import tariffs. The impact of DT on the volumes of imported capital and intermediate goods was also significant and of similar magnitudes. The variable DT was not significant in the VAR models for consumer goods, probably reflecting the government strategy of trade liberalization which kept consumer good's industries relatively more protected than others. Unfortunately, no satisfactory data were found on the evolution of tariffs by individual import categories. Finally, model (24) indicates that the volume of oil imports is considerably less elastic to domestic economic activity than all other import categories, while its responsiveness to the REER is similar to that of aggregate imports.

\footnotetext{
${ }^{14}$ Cointegration models would not be appropriate for these purposes since the series for oil import volumes was found to be stationary and the discrete changes in import tariffs are captured through a dummy variable that may alter the critical values used in the cointegration tests (see Johansen 1995).

${ }^{15}$ Data on average import tariffs were obtained from the World Bank.
} 
Table 4: Selected Import VARs and the Impact of Tariffs on Import Volumes

\begin{tabular}{|c|c|c|c|c|c|c|}
\hline Model & DRGDP & DREER & TD & QD & Adj. & SC \\
\hline \multicolumn{7}{|c|}{ Total Imports } \\
\hline (21) & 2.8 & 0.42 & -0.5 & Yes & 0.68 & -1.37 \\
\hline \multicolumn{7}{|c|}{ Imports of Intermediate Goods } \\
\hline (22) & 3.3 & 0.56 & -0.4 & Yes & 0.59 & -1.22 \\
\hline \multicolumn{7}{|c|}{ Imports of Capital Goods } \\
\hline (23) & 2.7 & 0.33 & -0.5 & Yes & 0.63 & -0.56 \\
\hline \multicolumn{7}{|c|}{ Imports of Oil } \\
\hline (24) & 1.8 & 0.40 & & Yes & 0.44 & -0.09 \\
\hline
\end{tabular}

\section{c) Further implications of estimated trade elasticities}

The elasticities estimated in this paper provide additional evidence that market analysts have been excessively pessimistic regarding the response of the Brazilian trade balance to a depreciation of the real exchange rate. Simple calculations using (i) the trade accounts at the end of the year 2000 as a starting point; (ii) market expectations of economic growth and the real depreciation of the BRL during 2001-02 as inferred in October 2001 (and depicted in Figure 2); and (iii) the average import and export elasticities estimated would have projected the 2002 trade surplus at about US\$12.7 billion. This figure is significantly higher than what was expected in October 2001 (US\$4.5 billion) and twice as high as what was expected even as of August 2002 (US\$6 billion). The trade surplus observed in 2002 was US\$13 billion.

Looking forward, the elasticities estimated in this paper can be used to broadly assess the impact of a programmed increase in the GDP growth rate on the trade balance and its potential implications for the exchange rate and inflation targets. The econometric estimates presented in the previous section suggest that the income elasticity of imports may be almost twice the income elasticity of exports in Brazil. Applying a Hodrick-Prescott filter (HP) on the quarterly series for partner countries' GDP in the period 1990-2001 yields a trend growth rate of about 2.7 percent a year. ${ }^{16}$ The program of the Brazilian government aims at increasing real GDP growth to at least 4 percent a year. If Brazil managed to achieve this targeted growth while its main trade partners grew at the trend rate of 2.7 percent, and given the estimated relative export and import income elasticities, Brazil's import volumes would be growing at a rate nearly 8 percentage points higher than its exports, everything else equal.

Therefore, under current conditions, in order to avoid a deterioration of the trade balance as Brazil grows faster than its trading partners, the real effective exchange rate of the BRL would come under renewed pressure to depreciate. Relying on a nominal depreciation

${ }^{16}$ The smoothing parameter used was 1600 , deemed more appropriate for quarterly series. 
to help achieve this objective would substantially constrain the ability of the Brazilian government to bring inflation back within the targeted band. Our estimates therefore obviate the importance of additional structural reforms that could improve the competitiveness of the Brazilian economy and the country's access to external financing so as to allow for higher sustainable economic growth without further exchange rate and inflationary pressures.

\section{ConCluding Remarks}

This paper provided an econometric analysis of trade elasticities in Brazil. We estimated export and import models through cointegration and unrestricted vector autoregression techniques and using quarterly data for the period 1990-2001. Cointegration models indicate that:

- Brazilian exports and imports have long-run income and real effective exchange rate elasticities which are in line with the international experience. Import elasticities are also in line with previous studies on Brazil.

- Real exchange rate volatility has a negative impact on export volumes and slows the adjustment of exports toward their long-run levels implied by fundamentals; the estimated elasticity of export volumes to the trend REER increases when the effect of real exchange rate volatility is factored in.

- The level of capacity utilization in manufacturing exerts a negative impact on export volumes; exports appear to be more elastic to external demand when this supply constraint is included in the model.

- The level of capacity utilization has a positive impact on imports; the estimated elasticity of imports to domestic income declines when the level of capacity utilization is included in the model, suggesting that economic growth poses a greater pressure on imports when domestic manufacturing is already operating at high levels of capacity utilization.

Unrestricted autoregression models confirm that the reduction of average tariffs implemented through the 1990s had a positive impact on aggregate import volumes. Introducing average tariffs in the empirical modeling leads to a decrease in the estimated elasticity of imports with respect to domestic demand. Nonetheless, only the imports of intermediate and capital goods were found to be significantly affected by changes in average tariffs. This result probably reflects the strategy of trade liberalization in Brazil, which has so far concentrated on intermediate and capital goods.

Contrary to what some recent surveys of market expectations implied, the responsiveness of Brazilian trade flows to the real exchange rate was found to be significant and broadly in line with those of other developing economies. However, because the elasticity of imports to domestic income seems to be approximately twice as high as the elasticity of exports to foreign income, Brazil's ambition to achieve economic growth rates that are equal to or above the growth rates of its main trading partners is likely to put pressure on the exchange rate to depreciate. 
Finally, while our estimates dismiss the market's trade elasticity pessimism detected in 2001, it also underscores the importance of implementing additional structural reforms in order to increase the efficiency and competitiveness of the Brazilian economy. These reforms would be instrumental in minimizing the exchange rate depreciation needed to preserve external sustainability amid accelerating economic growth and thus in facilitating the reduction of inflation toward the target band. 


\section{REFERENCES}

Aristotelous, Kyriacos, 2001, "Exchange-Rate Volatility, Exchange-Rate Regime, and Trade Volume: Evidence from the UK-US Export Function (1889-1999)," Economics Letters, Vol. 72 (July), pp. 87-94.

Arize, Augustine C., 1995, “Trade Flows and Real Exchange-Rate Volatility: An Application of Cointegration and Error-Correction Modeling," North American Journal of Economics and Finance, Vol. 6 (Spring), pp. 37-51.

_- Thomas Osang, and Daniel J. Slottje, 2000, "Exchange-Rate Volatility and Foreign Trade: Evidence from Thirteen LDC's," Journal of Business and Economic Statistics, Vol. 18 (January), pp. 10-17.

Baer, Werner, 2001, The Brazilian Economy: Growth and Development, (Westport, Conn.: Praeger, $5^{\text {th }}$ ed.).

Brazilian Central Bank, Inflation Report,(Brazil: various issues).

Bughin, Jacques, 1996, "Capacity Constraints and Export Performance: Theory and Evidence from Belgian Manufacturing," The Journal of Industrial Economics, Vol. 44 (June), pp. 187-204.

Caporale, Guglielmo Maria, and Michael K. F. Chui, 1999, "Estimating Income and Price Elasticities of Trade in Cointegration Framework," Review of International Economics, Vol. 7 (Issue 2), pp. 254-64.

Carvalho, Alexandre, and Maria Andreia Parente, 1999, "Estimação de Equações de Demanda de Importações por Categorias de Uso para o Brasil (1978/1996),", IPEA Discussion Paper No. 636 (Rio de Janeiro: Instituto de Pesquisa Econômica Aplicada).

Cavalcanti, Marco Antônio F. H, and Fernando José Ribeiro, 1998, "As Exportações Brasileiras no Período 1977/96: Desempenho e Determinantes," IPEA Discussion Paper No. 545 (Rio de Janeiro: Instituto de Pesquisa Econômica Aplicada).

Darrat, A. F., and, S. R. Hakim, 2000, "Exchange-Rate Volatility and Trade Flows in An Emerging Market: Some Evidence from a GARCH Process," Savings and Development, Vol. 24 (No. 3), pp. 287-302.

Devereux, Michael B., and Charles Engel, 2002, "Exchange Rate Pass-Through, Exchange Rate Volatility, and Exchange Rate Disconnect," Journal of Monetary Economics, Vol. 49, (Issue 5), pp. 913-40.

Enders, Walter, 1995, Applied Econometric Time Series (New York: Wiley). 
Figueiredo, Luiz Fernando, Pedro Fachada, and Sérgio Goldenstein, 2002, "Monetary Policy in Brazil: Remarks on Inflation Targeting Regime, Public Debt Management and Open Market Operations," Central Bank of Brazil Working Paper No. 37 (Brasília: Banco Central do Brasil).

Harvey, Andrew C., 1993, Time Series Models (Hemel Hempstead: Harvester Wheatsheaf, $2^{\text {nd }}$ ed.).

Jackson, John D., and David J. Smyth, 1985, "Specifying Differential Cyclical Response in Economic Time Series; Capacity Utilization and Demand for Imports," Economic Modelling, Vol. 2 (April), pp. 149-61.

Jeanne, Olivier, and Andrew K. Rose, 2002, "Noise Trading and Exchange Rate Regimes," Quarterly Journal of Economics, Vol. 117 (No. 2), pp. 537-69.

Johansen, Søren, 1988, "Statistical Analysis of Cointegration Vectors," Journal of Economic Dynamics and Control, Vol. 12 (June-September), pp. 231-54.

— 1991, "Estimation and Hypothesis Testing of Cointegration Vectors in Gaussian Vector Autoregressive Models," Econometrica, Vol. 59 (November), pp. 1551-80.

—_ 1995, Likelihood-Based Inference in Cointegrated Vector Autoregressive Models, (Oxford; New York: Oxford University Press).

Krugman, Paul, 1989, "Differences in Income Elasticities and Trends in Real Exchange Rates," European Economic Review, Vol. 33 (May), pp. 1031-54.

Maldonado, Wilfredo L., Octávio Augusto Fontes Tourinho, and Marcos Valli, 2002, "Um Teste de Existência de Bolhas na Taxa de Câmbio no Brasil," IPEA Discussion Paper No. 881 (Rio de Janeiro: Instituto de Pesquisa Econômica Aplicada).

McKenzie, Michael D. 1999, "The Impact of Exchange Rate Volatility on InternationaI Trade Flows," Journal of Economic Surveys, Vol. 13 (February), pp. 72-106.

Muinhos, Marcelo Kfoury, 2001, "Inflation Targeting in an Open Financially Integrated Emerging Economy: The Case of Brazil," Central Bank of Brazil Working Paper No. 26, (Brasília: Banco Central do Brasil).

Resende, Marco F. C., 2001, "Crescimento Econômico, Disponibilidade de Divisas e Importações no Brasil: um Modelo de Correção de Erros," Pesquisa e Planejamento Econômico, Vol. 31 (No. 2), pp. 289-330. 
Senhadji, Abdelhak, 1998, "Time-Series Estimation of Structural Import Demand Equations: A Cross-Country Analysis," Staff Papers, International Monetary Fund, Vol. 45 (No. 2), pp. 236-68.

Equations: A Cross-Country Analysis," Staff Papers, International Monetary Fund, Vol. 46 (No. 3), pp. 259-73. 